\title{
Perbedaan Mual dan Muntah Ibu Hamil Trimester I yang Diberikan Ekstrak Jahe dan Ekstrak Daun Mint
}

\author{
Anita $^{1}$, Aprina $^{2}$, Ratna Aryani ${ }^{3}$ \\ ${ }^{1,2}$ Jurusan Keperawatan, Politeknik Kesehatan Tanjungkarang, Indonesia \\ ${ }^{3}$ Jurusan Keperawatan, Politeknik Kesehatan Jakarta I, Indonesia \\ Email: anitabustami@yahoo.co.id
}

\begin{abstract}
Differences in Pregnant Women First Trimester Nausea and Vomiting Given Ginger Extract and Mint Leaf Extract. Study of literature with meta-analysis was obtained 7 out of 10 women around the world to experience nausea and vomiting during pregnancy, with an average incidence of $69.4 \%(66.5-72.3 \%$, CI 95\%). The purpose of research to find out the difference of nausea and vomiting of pregnant women through assessment scale Rhodes after administration of ginger extract and mint leaf extract in Inpatient Health Center Bandar Lampung in 2016. The target of research is the discovery of alternative therapy/food in the community to reduce nausea and vomiting of pregnant women. Type of research is quantitative research, design experimental research. The study population is the entire first-trimester pregnant women who visit health centers Inpatient Bandar Lampung, with 10 (ten) PHC hospitalization. The total sample was 102, the group treated with the extract of ginger were 34 respondents, a group treated extract of mint leaves were 34 respondents, and the group without treatment who received standard procedures health centers (Vitamin B6) were 34 respondents, with the criteria of pregnant women the first trimester without GI disease. The results of the study there were significant differences between the measurement value of nausea and vomiting before and after administration of ginger extract, extract of mint and a control group with $\mathrm{p}=0.001$ in the extract of ginger, $\mathrm{p}=0.000$ in the extract mint, and $\mathrm{p}=0.001$ in the control group with (standard treatment of health centers with vitamin B6). There were no differences between mean nausea and vomiting in the first trimester pregnant women who received ginger extract and mint with a $\mathrm{p}=0.548$, ginger extract and control groups with $\mathrm{p}=0.807$, mint extract and control groups with $\mathrm{p}=0,407$ ginger and mint can be an alternative therapy to reduce vomiting and nausea of pregnant woman in trimester I. Advanced research about the composition, dosage and side effects of ginger and mint benefit to the problem of gastrointestinal disorders who experience nausea and vomiting.
\end{abstract}

Keywords: Extracts of ginger, Mint, Nausea, Vomiting

\begin{abstract}
Abstrak: Perbedaan Mual dan Muntah Ibu Hamil Trimester I yang Diberikan Ekstrak Jahe dan Ekstrak Daun Mint. Studi literatur dengan meta analisis diperoleh 7 dari 10 wanita di seluruh dunia mengalami mual muntah selama kehamilan, dengan rata-rata kejadian 69,4\% (66,5\%-72,3\%, CI 95\%). Tujuan penelitian untuk mengetahui perbedaan mual muntah ibu hamil melalui penilaian skala Rhodes setelah pemberian esktrak jahe dan ekstrak daun mint di Puskesmas Rawat Inap Bandar Lampung tahun 2016. Target penelitian adalah ditemukannya terapi alternatif/makanan yang ada di masyarakat untuk mengurangi mual muntah ibu hamil. Jenis penelitian kuantitatif, rancangan penelitian eksperimen. Populasi penelitian seluruh ibu hamil trimester I yang melakukan kunjungan di Puskesmas Rawat Inap Bandar Lampung, sejumlah 10 Puskesmas rawat inap. Jumlah sampel 102, kelompok perlakuan dengan pemberian ekstrak jahe sejumlah 34 responden, kelompok pemberian ekstrak daun mint 34 responden, dan kelompok tanpa perlakuan yang mendapatkan prosedur standar Puskesmas (Vitamin B6) sejumlah 34 responden, dengan kriteria ibu hamil trimester I tanpa penyakit saluran cerna. Hasil penelitian terdapat perbedaan signifikan antara pengukuran nilai mual muntah sebelum dan setelah pemberian ekstrak jahe, ekstrak mint dan kelompok kontrol dengan nilai $p=0,001$ pada pemberian ekstrak jahe, nilai $p=0,000$ pada pemberian ekstrak mint, dan $p=0,001$ pada kelompok kontrol (pengobatan standar puskesmas dengan vitamin B6). Tidak terdapat perbedaan rerata mual muntah ibu hamil trimester I yang mendapat ekstrak jahe dan mint dengan nilai $p=0,548$, ekstrak jahe dan kelompok kontrol dengan nilai $p=0,807$, ekstrak mint dan kelompok kontrol dengan nilai $p=0,407$ Jahe dan mint dapat menjadi terapi alternatif mengurangi mual muntah ibu hamil trimester I. Penelitian lanjut tentang komposisi, dosis efek samping serta kemanfaatan jahe dan mint terhadap masalah gangguan saluran cerna yang mengalami mual dan muntah ringan.
\end{abstract}

Kata kunci: Ekstrak jahe, Daun mint, Mual, Muntah 
Menurut World Health Organization (WHO) jumlah kejadian hiperemesis gravidarum mencapai $12,5 \%$ dari seluruh jumlah kehamilan di dunia. Kunjungan pemeriksaan kehamilan ibu hamil di Indonesia diperoleh data ibu dengan hiperemesis gravidarum mencapai $14,8 \%$ dari seluruh kehamilan (Depkes RI, 2013). Mual dan muntah merupakan keluhan utama yang paling umum dirasakan oleh wanita hamil hampir setiap tahunnya di seluruh dunia (Einarson, Piwko, \& Koren, 2013). Mual muntah menjadi salah satu indikator bahwa seorang wanita sedang mengalami kehamilan (Chan et al., 2011). Istilah populer untuk keluhan ini adalah morning sickness (White \& Leon-casasola, 2009). Morning sickness/ emesis gravidarum merupakan keluhan umum yang disampaikan oleh wanita hamil muda yang ditandai dengan mual muntah pada pagi hari, keluhan ini sebenarnya dapat terjadi sepanjang hari yang bila dibiarkan akan mempunyai efek yang serius (The American College of Obstetricians and gynecologists, 2015). Kejadian Morning sickness pada wanita hamil didunia adalah 70-80 \% dan 1,5 sd $2 \%$ mengalami hiperemisis gravidarum (Prawiharjo, 2010).

Einarson et al., (2013) dalam penelitian studi literatur dengan meta-analis menyebutkan bahwa 7 dari 10 wanita di seluruh dunia mengalami mual muntah selama kehamilan dengan rata-rata kejadian sebesar 69,4\% (66.5\%$72.3 \%$, C195\%). Tidak jauh berbeda, Heitmann, Holst, Lupattelli, Maltepe, \& Nordeng (2015) dalam penelitiannya dengan metode crosssectional pada 9113 wanita hamil di 5 negara bagian Eropa, Amerika dan Australia mengemukakan bahwa $73,5 \%$ wanita hamil mengalami mual selama kehamilan. Onset, durasi dan tingkat keparahan mual muntah tersebut bersifat individual dan berbeda-beda antar sesama wanita hamil, bahkan antar kehamilan di individu yang sama (Chan et al., 2011).

Mual muntah dapat memberikan dampak pada klien, baik secara fisik ataupun psikologis. Isbir \& Mete (2013) dalam penelitian kualitatifnya mendeskripsikan dampak secara fisik akibat mual muntah pada wanita hamil adalah kelemahan, perubahan pola tidur, penurunan nafsu makan, nyeri inguinal, adanya sensasi terbakar dan iritasi tenggorokan, ketosis serta inkontinensia urin. Jika dampak fisik terjadi terus menerus dan tidak diintervensi, maka akan menyebabkan Hiperemesis Gravidarum (Heitmann et al., 2015). Kondisi ini memerlukan perawatan di Rumah Sakit dan biasa terjadi pada 1.1\% wanita hamil (Einarson et al., 2013).
Isbir \& Mete (2013) menyebutkan dampak psikologis akibat mual muntah, yaitu adanya perasaan lemah, sering menangis, minim perawatan diri, perubahan hubungan seksual, menjadi tidak bertanggungjawab pada pekerjaan rumah tangga ataupun kantor serta adanya ketidakpuasan dalam hubungan sosial. Mual muntah pada wanita hamil juga berpengaruh negatif terhadap hubungan antara klien dengan keluarganya, perannya di rumah, pekerjaan ataupun kehidupan sosialnya (Lacasse, Rey, Ferreira, Morin, \& Bérard, 2009; Locock, Alexander, \& Rozmovits, 2008).Penelitian yang dilakukan oleh Munch, Korst, Hernandez, Romero, \& Goodwin (2010) menyatakan bahwa wanita hamil dengan kondisi Hiperemesis Gravidarum mempunyai kualitas hidup 3-6 kali yang lebih rendah dibandingkan wanita hamil yang mengalami mual muntah saja.

Heitmann, Holst, Lupattelli, Maltepe, \& Nordeng (2015) menyebutkan bahwa salah satu usaha yang sering dilakukan wanita hamil untuk mengatasi mual muntahnya adalah mengkonsumsi obat konvensional $(17,9 \%)$ atau obat herbal (8,3\%). Penggunaan obat-obatan memang dibutuhkan oleh $10 \%$ wanita hamil dengan mual muntah, termasuk vitamin B6, antihistamin, prokinetic agent dan obat lainnya (Niebyl, 2010). Penggunaan pilihan obat tersebut dipengaruhi karena adanya perbedaan kultur dan sikap terhadap pengobatan. Tidak jauh berbeda, Bishop, Northstone, Green, \& Thompson (2011) juga menyebutkan bahwa $1 / 4$ wanita hamil di Inggris memanfaatkan Complementary And Alternative Medicine (CAM) paling tidak $1 \mathrm{x}$ selama kehamilan.

Salah satu herbal yang dimanfaatkan untuk mengurangi mual muntah pada kehamilan adalah pemberian ekstrak jahe dan daun mint karena dianggap sebagai obat yang aman pada kehamilan. Penelitian terkait keduanya pun sudah ada, walaupun fenomena pemanfaatan ekstrak jahe dan daun mint belum banyak dilakukan. Padahal Jahe dan daun mint mempunyai banyak keunggulan serta mudah diperoleh di masyarakat. Ozgoli, Goli, \& Simbar (2009) dalam penelitian single blind clinical trial study pada wanita hamil yang diberi ekstrak jahe menyebutkan bahwa keluhan mual muntah mengalami penurunan jika dibandingkan wanita hamil yang diberikan plasebo. Penelitian ini juga menyimpulkan bahwa ekstrak jahe adalah obat herbal yang efektif dalam menurunkan mual dan muntah selama kehamilan. Selain jahe, daun mint juga dimanfaatkan untuk mengurangi mual muntah. Penelitian yang dilakukan oleh Pasha, Behmanesh, Mohsenzadeh, Hajahmadi, \& Aa, 
(2014) menyebutkan bahwa tingkat keparahan mual muntah pada ibu hamil selama di-intervensi dengan mint mengalami penurunan (terutama di hari ke-4 intervensi), sedangkan di kelompok yang tidak diintervensi mengalami trend yang meningkat. Pada hari ke-7 mual dan muntah pada kedua kelompok mengalami penurunan, walaupun pada kelompok intervensi mint menunjukkan intensitas yang lebih rendah.

Wilayah Kota Bandar lampung memiliki jumlah 30 puskesmas terdiri dari 12 puskesmas perawatan dan 18 non keperawatan dimana merupakan jumlah puskesmas yang terbanyak di wilayah Provinsi Lampung. Provinsi Lampung tahun 2014 dari 182.815 ibu hamil yang mengalami emesis gravidarum sebesar $60-50 \%$ (95.826 orang) yang berlanjut menjadi hiperemesis gravidarum mencapai $10-15 \%$ (25.500 orang), sedangkan di Kota Bandar Lampung yang mengalami hiperemesis gravidarum sebanyak $25 \%$ dari 22.791 orang (Dinas Kesehatan Propinsi Lampung, 2014).

Berdasarkan data pre survey yang dilakukan peneliti pada Bulan Januari 2016 di Puskesmas Sukarame Bandar Lampung yang merupakan salah satu puskesmas perawatan di wilayah Kota Bandar Lampung dengan cara mengobservasi buku kunjungan ibu hamil diketahui terdapat 48 wanita hamil trimester I. Berdasarkan jumlah tersebut, terdapat $37(77,0 \%)$ wanita hamil mengalami mual dan muntah namun tidak berlebihan, 3 (6,2\%) wanita hamil mengalami mual muntah yang berlebihan, 8 $(16,7 \%)$ wanita hamil mengeluh pusing dan lainnya tidak ada keluhan apapun.

Upaya mengatasi keluhan ibu hamil, petugas kesehatan memberikan obat anti mual (vitamin B6) dan konseling pada pola makan. Petugas kesehatan belum mencoba memberikan konseling yang berkaitan dengan minuman ekstrak jahe maupun daun mint untuk mengurangi mual muntah.

\section{METODE}

Jenis penelitian kuantitatif. Desain eksperimen, skema berikut :

Kelompok eksperimen A: $\mathrm{O}_{1}-------\mathrm{X}_{1}------\mathrm{O}_{2}$

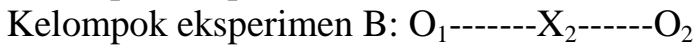
Kelompok kontrol $\quad: \mathrm{O}_{1}------\mathrm{X} 3-----\mathrm{O}_{2}$

Keterangan:

$X_{1}=$ Pemberian ekstrak jahe; $X_{2}=$ Pemberian ekstrak daun mint; $X_{3}=$ Kontrol (pemberian obat standar puskesmas)
Penelitian dilaksanakan pada 15 Juni sampai 31 November 2016, lokasi penelitian ini dilaksanakan di 10 (sepuluh) Puskesmas Rawat Inap Bandar Lampung. Populasi penelitian seluruh ibu hamil trimester I yang melakukan kunjungan di Puskesmas Rawat Inap Bandar Lampung. Total sampel 102 ibu hamil, dengan perbandingan $1: 1: 1$, dimana 34 responden di intervensi ekstrak jahe, 34 responden simplisia/ ekstrak daun mint, dan 34 responden di intervensi vitamin B6. Teknik sampling purposive sampling, kriteria inklusi sampel ibu mengeluh mual muntah, tidak memiliki penyakit lambung/saluran cerna dan tidak mengalami gangguan psikologis.

Prosedur Penelitian, Ibu hamil yang memenuhi kriteria inklusi, dilakukan inform consent, Sebelum dan setelah 12 jam intervensi responden mengisi kuesioner skala Rhodes sejumlah 8 pertanyaan dengan penilaian skala 0 4, perlakuan diberikan selama 6 hari.

Analisis data yang digunakan adalah statistik deskriptif berupa prosentase, data mean, standar deviasi dan standar error mean. Statistik inferensial dengan melakukan uji chi square dan uji t dependen dan independen.

\section{HASIL}

Tabel 1. Distribusi Responden Berdasarkan Karakteristik Responden

\begin{tabular}{|c|c|c|c|c|c|c|c|c|}
\hline \multirow{3}{*}{ Karakteristik } & \multicolumn{6}{|c|}{ Intervensi } & & \\
\hline & \multicolumn{2}{|c|}{$\begin{array}{c}\text { Ekstrak } \\
\text { jahe }\end{array}$} & \multicolumn{2}{|c|}{$\begin{array}{c}\text { Ekstrak } \\
\text { mint }\end{array}$} & \multicolumn{2}{|c|}{ Vit. B6 } & \multicolumn{2}{|c|}{ Total } \\
\hline & $\mathbf{n}$ & $\%$ & $\mathbf{n}$ & $\%$ & $\mathbf{n}$ & $\%$ & $\mathbf{n}$ & $\%$ \\
\hline \multicolumn{9}{|l|}{ Umur (tahun) } \\
\hline$<20 \&>35$ & 6 & 18 & 1 & 2 & 9 & 26 & 16 & 16 \\
\hline $20-35$ & 28 & 82 & 33 & 98 & 25 & 73 & 86 & 84 \\
\hline \multicolumn{9}{|l|}{ Paritas } \\
\hline Primigravida & 10 & 32 & 12 & 35 & 5 & 15 & 29 & 28 \\
\hline Multigravida & 22 & 68 & 22 & 64 & 29 & 85 & 73 & 72 \\
\hline \multicolumn{9}{|l|}{ Pendidikan } \\
\hline SD-SMP & 16 & 47 & 14 & 41 & 16 & 47 & 46 & 45 \\
\hline SMA-PT & 18 & 53 & 20 & 59 & 18 & 53 & 56 & 55 \\
\hline \multicolumn{9}{|l|}{ Pekerjaan } \\
\hline Tidak & 29 & 85,3 & 25 & 73,5 & 28 & 82,4 & 82 & 80 \\
\hline Bekerja & 5 & 14,7 & 9 & 26,5 & 6 & 17,6 & 20 & 20 \\
\hline Bekerja & & & & & & & & \\
\hline
\end{tabular}

Berdasarkan tabel 1 diketahui bahwa distribusi terbanyak responden pada usia 20-35 tahun sejumlah 86 (84\%), terbanyak pada paritas multigravida sejumlah 73 responden (72\%), pendidikan responden terbanyak pada kategori SMA-PT sejumlah 56 orang (55\%), sebagian besar responden tidak bekerja sejumlah 82 orang $(80 \%)$. 
Tabel 2. Pengaruh Umur, Pendidikan, Pekerjaan dan Paritas terhadap Mual Muntah Ibu Hamil Trimester I

\begin{tabular}{|c|c|c|c|c|c|c|}
\hline Karakteristik & $\begin{array}{l}\text { Mual } \\
\text { berat }\end{array}$ & $\%$ & $\begin{array}{c}\text { Mual } \\
\text { Ringan }\end{array}$ & $\%$ & $\begin{array}{c}p- \\
\text { value }\end{array}$ & $\begin{array}{c}\text { OR } \\
\text { (CI } \\
95 \%) \\
\end{array}$ \\
\hline \multicolumn{7}{|l|}{ Umur } \\
\hline $\begin{array}{l}<20 \text { dan }>35 \\
\text { tahun }\end{array}$ & 8 & 8 & 4 & 4 & \multirow[t]{2}{*}{0,423} & \\
\hline 20-35 tahun & 49 & 48 & 41 & 40 & & \\
\hline \multicolumn{7}{|l|}{ Pendidikan } \\
\hline $\begin{array}{l}\text { SD-SMP } \\
\text { SMA-PT }\end{array}$ & $\begin{array}{l}21 \\
36\end{array}$ & $\begin{array}{l}21 \\
35\end{array}$ & $\begin{array}{l}25 \\
20\end{array}$ & $\begin{array}{l}25 \\
20\end{array}$ & 0,060 & \\
\hline \multicolumn{7}{|l|}{ Pekerjaan } \\
\hline $\begin{array}{l}\text { Tidak Bekerja } \\
\text { Bekerja }\end{array}$ & $\begin{array}{l}44 \\
13\end{array}$ & $\begin{array}{l}43 \\
13\end{array}$ & $\begin{array}{r}38 \\
7\end{array}$ & $\begin{array}{r}37 \\
7\end{array}$ & 0,360 & \\
\hline \multicolumn{7}{|l|}{ Paritas } \\
\hline Primigravida & 22 & 22 & 7 & 7 & & 3,412 \\
\hline Multigravida & 35 & 34 & 38 & 37 & 0,01 & $\begin{array}{r}(1,298- \\
8,970)\end{array}$ \\
\hline
\end{tabular}

Berdasarkan hasil uji statistik pada tabel 2 maka disimpulkan bahwa tidak ada pengaruh umur, pendidikan dan pekerjaan terhadap mual muntah ibu hamil trimester I, berturut-turut nilai $p=0,423,0,06,0,360$ dan terdapat pengaruh signifikan antara paritas dengan mual muntah yang terjadi pada ibu hamil trismester I nilai $p=0,01$, nilai OR 3,412 artinya ibu primigravida memiliki peluang mual muntah pada kehamilan trimester pertama sebanyak 3,4 kali dibandingkan ibu multigravida.

Tabel 3. Nilai Rerata Mual Muntah Pengukuran Sebelum dan Setelah' Intervensi Jahe, Mint dan Kontrol (Vitamin B6)

\begin{tabular}{lccccc}
\hline Intervensi & Mean & SD & SE & $\begin{array}{c}p- \\
\text { value }\end{array}$ & n \\
\hline Jahe & & & & & \\
Sebelum & 10,21 & 6,7 & 1,1 & 0,001 & 34 \\
Setelah & 6,53 & 5,5 & 0,9 & & \\
\hline Mint & & & & & \\
Sebelum & 10,65 & 6,4 & 1,1 & 0,000 & 34 \\
Setelah & 6,62 & 5,0 & 0,9 & & \\
\hline Kontrol (vitamin B6) & & & & \\
Sebelum & 10,12 & 6,4 & 1,09 & 0,001 & 34 \\
Setelah & 6,85 & 5,8 & 0,99 & & \\
\hline
\end{tabular}

Berdasarkan tabel 3 rata-rata nilai mual muntah pada pengukuran pertama sebelum diberikan ekstrak jahe adalah 10,21 dengan standar deviasi 1,1. Pada pengukuran kedua, setelah pemberian ekstrak jahe didapat rata-rata nilai 6,53 dengan standar deviasi 0,9 . Perbedaan nilai mean antara pengukuran sebelum dan setelah adalah 3,676 dengan standar deviasi 6,054. Hasil uji statistik didapatkan nilai $p=0,001$, maka dapat disimpulkan ada perbedaan yang signifikan antara pengukuran nilai mual muntah sebelum dan setelah pemberian ekstrak jahe.

Rata-rata nilai mual muntah pada pengukuran pertama sebelum diberikan ekstrak mint adalah 10,65 dengan standar deviasi 6,429. Pada pengukuran kedua, setelah pemberian ekstrak mint didapat rata-rata nilai 6,62 dengan standar deviasi 5,015. Perbedaan nilai mean antara pengukuran sebelum dan setelah adalah 4,029 dengan standar deviasi 4,945. Hasil uji statistik didapatkan nilai $p=0,0001$, maka dapat disimpulkan ada perbedaan yang signifikan antara pengukuran nilai mual muntah sebelum dan setelah pemberian ekstrak mint.

Rata-rata nilai mual muntah pada pengukuran pertama kelompok kontrol (pengobatan standar puskesmas) adalah 10,12 dengan standar deviasi 6,381. Pada pengukuran kedua, didapat rata-rata nilai 6,85 dengan standar deviasi 5,811. Perbedaan nilai mean antara pengukuran sebelum dan setelah adalah 3,265 dengan standar deviasi 5,089. Hasil uji statistik didapatkan nilai $p=0,001$, maka dapat disimpulkan ada perbedaan yang signifikan antara pengukuran nilai mual muntah sebelum dan setelah pada kelompok kontrol (pengobatan standar puskesmas dengan vitamin B6).

Perbedaan Rerata Mual Muntah Ibu Hamil Trimester I yang Diberikan Ekstrak Jahe, Ekstrak Daun Mint dan Kelompok Kontrol

Tabel 4. Nilai Rerata Mual Muntah antara Kelompok yang Diberikan Jahe, Mint dan Pengobatan Standar Puskesmas (Vitamin B6)

\begin{tabular}{lccccc}
\hline \multicolumn{1}{c}{ Intervensi } & Mean & SD & SE & $\begin{array}{c}p- \\
\text { value }\end{array}$ & $\mathbf{n}$ \\
\hline $\begin{array}{l}\text { Setelah } \\
\text { pemberian }\end{array}$ & & & & & \\
$\begin{array}{l}\text { Jahe } \\
\text { Mint }\end{array}$ & 6,5 & 5,5 & 0,95 & 0,548 & 34 \\
\hline $\begin{array}{l}\text { Setelah } \\
\text { pemberian }\end{array}$ & 6,6 & 5,0 & 0,86 & & \\
$\begin{array}{l}\text { Jahe } \\
\text { Kontrol }\end{array}$ & 6,5 & 5,5 & 0,95 & 0,807 & 34 \\
\hline $\begin{array}{l}\text { Setelah } \\
\text { pemberian }\end{array}$ & 6,9 & 5,8 & 0,99 & & \\
$\begin{array}{l}\text { Mint } \\
\text { Kontrol }\end{array}$ & 6,6 & 5,0 & 0,86 & 0,407 & 34 \\
\hline
\end{tabular}

Berdasarkan tabel 4 rata-rata nilai mual muntah ibu hamil yang mendapatkan ekstrak jahe adalah 6,53 dengan standar deviasi 5,512, sedangkan rata-rata nilai mual muntah ibu hamil yang mendapatkan ekstrak mint adalah 6,6 dengan standar deviasi 0,86 . Hasil uji statistik 
didapatkan nilai $p=0,548$, berarti pada alpha $5 \%$ terlihat tidak ada perbedaan yang signifikan ratarata mual muntah antara ibu yang mendapatkan ekstrak jahe dengan ibu yang mendapat ekstrak mint.

Rata-rata nilai mual muntah ibu hamil yang mendapatkan ekstrak jahe adalah 6,53 dengan standar deviasi 5,512. Sedangkan ratarata nilai mual muntah ibu hamil pada kelompok kontrol adalah 6,85 dengan standar deviasi 5,811. Hasil uji statistik didapatkan nilai $p=0,807$, berarti pada alpha 5\% terlihat tidak ada perbedaan yang signifikan rata-rata mual muntah antara ibu yang mendapatkan ekstrak jahe dengan ibu pada kelompok kontrol (pengobatan standar puskesmas/pemberian vitamin B6).

Rata-rata nilai mual muntah ibu hamil yang mendapatkan ekstrak mint adalah 6,62 dengan standar deviasi 5,015. Sedangkan ratarata nilai mual muntah ibu hamil pada kelompok kontrol adalah 6,85 dengan standar deviasi 5,811. Hasil uji statistik didapatkan nilai $p=0,407$, berarti pada alpha 5\% terlihat tidak ada perbedaan yang signifikan rata-rata mual muntah antara ibu yang mendapatkan ekstrak mint dengan ibu pada kelompok kontrol (pengobatan standar puskesmas/ pemberian vitamin B6).

\section{PEMBAHASAN}

\section{Karakteristik Responden}

Keluhan mual yang disertai atau tidak disertai muntah memang seringkali dikeluhkan wanita hamil, namun sedikit sekali penelitian yang meneliti faktor resiko dan perkembangannya. Penelitian ini memasukkan variabel umur, pendidikan, pekerjaan dan paritas sebagai faktor resiko.

Hasil penelitian ini menyebutkan bahwa usia terbanyak ibu hamil yang mengalami mual muntah berada pada rentang usia 20-35 tahun (84\%). Hal ini tidak jauh berbeda dengan penelitian yang dilakukan oleh Louik, Hernandez-Diaz, Werler, \& Mitchell (2006) yang menyebutkan bahwa rata-rata ibu hamil yang mengalami mual muntah paling banyak berada pada rentang usia $26-30$ tahun $(67,2 \%)$ dimana semakin bertambah usia ibu maka resiko mual muntah akan menurun, namun ibu hamil yang berusia 40 tahun atau lebih akan beresiko 4,7 kali lipat mengalami mual muntah. Penelitian Louik et al, ini juga menyatakan bahwa ada hubungan yang kuat antara usia wanita hamil dengan kejadian mual muntah $(p=0,001)$.
Terkait usia ibu dan kejadian mual muntah pada kehamilan, penelitian Chan et al. (2011) menyatakan hal yang lebih spesifik lagi, dimana wanita hamil yang mengalami mual saja didominasi pada rentang usia 25-29 tahun $(33,1 \%)$ dan yang mengalami mual serta muntah berada pada rentang $<25$ tahun $(38,5 \%)$. Dalam penelitiannya, dinyatakan bahwa ibu hamil yang berusia 40 tahun atau lebih akan beresiko 4,7 kali lipat mengalami mual muntah. Mereka juga menyatakan bahwa ada hubungan yang kuat antara usia wanita hamil dengan kejadian mual muntah $(p=0,001)$. Semakin muda ibu hamil maka kecenderungannya mengalami mual muntah akan semakin menurun, namun ibu yang lebih sering mengalami kehamilan akan lebih beresiko timbulnya keluhan mual muntah.

Berdasarkan temuan penelitian ini dan penelitian sebelumnya, dapat disimpulkan bahwa perawat haruslah memberikan edukasi pada ibu yang ingin hamil untuk memperhatikan pada saat umur berapakah ia sebaiknya hamil. Perawat juga harus memberikan perhatian khusus kepada ibu hamil dengan usia yang terlalu muda. Lee \& Saha, (2011) menyatakan bahwa salah satu karakteristik ibu hamil yang paling sering ditemui mengalami mual muntah adalah usia ibu yang terlalu muda (tidak disebutkan rentang usianya).

Terkait dengan paritas, penelitian ini menyimpulkan bahwa ibu hamil yang mengalami mual muntah dengan paritas primigravida sejumlah 28 responden $(27 \%)$ dengan nilai Rhodes berada pada rentang sedang sampai berat, bila dibandingkan dengan multi gravida yang berada pada rentang bervariasi mulai dari ringan sampai berat/ lebih banyak pada rentang ringan. Hasil penelitian ini mempunyai hasil yang sama dengan yang dilakukan oleh Lee. \& Saha (2011) yang menyatakan bahwa primigravida termasuk kategori ibu hamil yang beresiko tinggi terjadi mual muntah. Hasil 2 penelitian tersebut tidak sama dengan yang dilakukan Louik, HernandezDiaz, Werler, \& Mitchell (2006)yang menyimpulkan bahwa risiko kejadian mual muntah akan bertambah dengan seringnya seseorang mengalami kehamilan.

Louik et al., (2006) menambahkan bahwa antara ibu yang melahirkan neonatus dengan kelainan kongenital dan ibu dengan neonatus yang normal sama-sama mengalami kejadian mual muntah, namun ibu dengan kehamilan kembar akan beresiko lebih tinggi terhadap keluhan mual muntah daripada ibu dengan kehamilan tunggal. Semakin sering ibu mengalami keguguran, maka resiko mengalami mual muntah juga akan semakin tinggi. 
Penelitian ini menyebutkan bahwa hanya $17 \%$ ibu yang memiliki pendidikan tinggi SMA dan Perguruan Tinggi (PT) dan $80 \%$ tidak memiliki pekerjaan (diasumsikan mempunyai tingkat pendapatan yang lebih rendah daripada ibu yang bekerja. Hasil penelitian ini relatif sama dengan penelitian yang dilakukan oleh Lee. \& Saha, (2011) yang menyatakan bahwa salah satu karakteristik ibu hamil yang mengalami mual muntah lebih sering ditemui pada perempuan yang memiliki pendidikan $<12$ tahun dan mempunyai tingkat pendapatan yang rendah.

Hasil penelitian di atas juga mendukung penelitian yang dilakukan Louik et al. (2006) yang menyatakan bahwa tidak ada perbedaan yang signifikan antara ibu hamil yang memiliki ataupun tidak memiliki pekerjaan. Namun demikian, mereka menyatakan bahwa ibu hamil yang mengalami mual muntah lebih dari trimester 1 , pada umumnya mempunyai tingkat pendidikan dan penghasilan yang lebih rendah.

Berdasarkan hasil penelitian yang dilakukan dan penelitian terdahulu, peneliti menyimpulkan bahwa pendidikan dan jumlah penghasilan tidak mempengaruhi kejadian mual muntah. Meskipun pendidikan dan jumlah penghasilan/pekerjaan akan mempengaruhi seseorang dalam mengatur pola hidup ataupun memotivasi untuk mengakses pelayanan kesehatan (Louik et al., 2006). Hal ini dikarenakan rendahnya pendidikan seseorang akan membuat seseorang makin sedikit keinginan untuk memanfaatkan pelayanan kesehatan dan semakin tinggi pendidikan seseorang akan membuat seseorang semakin mudah untuk menerima informasi dan memanfaatkan pelayanan kesehatan yang ada. Kesimpulan tidak ada hubungan antara pendidikan dan pekerjaan dimungkinkan karena faktor budaya yang mendahulukan pria untuk mengikuti pendidikan tinggi dan bekerja, sebagai penghasil utama pendapatan keluarga.

\section{Perbedaan Mual Muntah Ibu Hamil Trimester I Sebelum dan Setelah Pemberian Ekstrak Jahe}

Penelitian ini menyimpulkan bahwa ada perbedaan rata-rata antara ibu hamil yang mengalami mual muntah sebelum dan sesudah intervensi dengan ekstrak jahe. Hal ini sesuai dengan penelitian yang dilakukan oleh (Ozgoli et al., 2009). Ozgoli, Goli, \& Simbar (2009) yang melakukan single blind clinical trial study pada 67 wanita hamil dengan keluhan mual muntah di Rumah Sakit Isfahan City. Grup intervensi menerima $250 \mathrm{mg}$ ekstrak jahe dalam bentuk kapsul selama 4 hari, sedangkan kelompok kontrol menerima plasebo. Efektifitas intervensi terhadap kejadian mual muntah dievaluasi $2 x$ sehari selama 4 hari. Berdasarkan penelitian tersebut, diketahui bahwa karakteristik responden pada kelompok intervensi dan kelompok kontrol mempunyai rata-rata usia $24.1 \pm 4.8$ dan $23.3 \pm 5$ tahun, rata-rata usia kehamilan $13 \pm 3$ minggu dan rata-rata paritas $1,3 \pm 1,6$. Penelitian tersebut menyebutkan bahwa wanita hamil yang diberi ekstrak jahe mengalami perbaikan dalam mengatasi mualnya dibandingkan yang diberikan plasebo (85\% vs 56\%; p-value 0.01). Penurunan keluhan muntah juga menurun secara signifikan pada kelompok intervensi $(50 \%$ vs $9 \%$; $p$-value 0.05). Penelitian ini menyimpulkan bahwa ekstrak jahe adalah obat herbal yang efektif dapat menurunkan mual dan muntah selama kehamilan.

Penelitian ini juga memberikan hasil yang sama dengan hasil penelitian Kikak, Choiriyah, \& Trisnasari (2013), yang menyatakan bahwa terdapat efektifitas penurunan mual muntah pada ibu hamil di wilayah kerja puskesmas Ungaran pada kelompok kontrol dan intervensi (pemberian jahe) dengan nilai $p$-value sebesar 0,044 .

Hasil penelitian ini berbeda dengan penelitian yang dilakukan oleh Viljoen, Visser, Koen, \& Musekiwa (2014) dengan menggunakan 12 randomized controlled trials (RCTs) tentang efektifitas jahe sebagai pilihan dalam mengatasi mual muntah pada wanita hamil. Disimpulkan bahwa jahe memang secara signifikan berpengaruh positif terhadap kejadian mual muntah jika dibandingkan dengan plasebo (MD $1.20,95 \%$ CI $0.56-1.84, p=0.0002, \quad \mathrm{I} 2=0 \%$ ), namun tidak signifikan menurunkan frekuensi muntah, walaupun trend nya mengalami perbaikan (MD 0.72, 95\% CI -0.03-1.46, $p=0.06$, $\mathrm{I} 2=71 \%$ ). Penelitian Viljoen juga menyimpulkan bahwa jahe tidak memyebabkan efek samping dan efektif jadikan pilihan.

Terkait hasil penelitian ini, maka meminimalisir adanya mual dan muntah ataupun mencegah terjadinya mual muntah sehingga terjadinya Hiperemesis Gravidarum pada ibu hamil merupakan hal penting yang harus diperhatikan perawat. Tenaga kesehatan harus memberikan edukasi bagaimana cara mengkonsumsi herbal dengan tepat, serta menjelaskan efek samping (Broussard et al., 2010). Adanya mual muntah tentu saja akan mempengaruhi kualitas hidup ibu hamil. Penelitian Munch et al. (2010) menyebutkan bahwa ibu hamil yang mengalami mual muntah atau Hiperemesis Gravidarum akan mempunyai kualitas hidup lebih rendah 3-6 kali jika 
dibandingkan dengan ibu hamil yang mengalami mual muntah yang umum dirasakan ibu hamil.

\section{Perbedaan Mual Muntah Ibu Hamil Trimester I Sebelum dan Setelah Pemberian Ekstrak Mint}

Hasil penelitian menunjukkan bahwa ada perbedaan rata-rata antara ibu hamil yang mengalami mual muntah sebelum dan sesudah intervensi dengan ekstrak mint. Daun mint memiliki efek anestesia yang berguna untuk mengatasi kram perut. Selain itu, daun mint terbukti mampu mengatasi perut kembung dan menghilangkan rasa mual. Hal ini karena daun mint mencegah terjadinya pembentukan gas di dalam perut. Daun mint memiliki kandungan menthol yang terbukti memiliki sifat stimulant yang berguna untuk membantu memperlancar gangguan pencernaan. Kandungan antispasmodic pada daun mint berkhasiat untuk mengendurkan atau mengatasi rasa sakit pada otot-otot tubuh. Daun mint mengandung Menthol, yang memiliki efek antispasmodik langsung pada otot polos saluran pencernaan. Daun mint juga membantu otot-otot di sekitar usus untuk rileks dan mencegah produksi gas. Kemampuan untuk menenangkan kram otot perut membuatnya menjadi pengobatan yang luar biasa untuk mengatasi gejala gangguan pencernaan. Daun mint membantu dalam mengurangi mual dan morning sickness selama kehamilan.

Hasil penelitian ini mendukung penelitian Broussard et al., (2010) yang menyatakan daun Mint merupakan salah satu herbal yang paling sering digunakan pada ibu hamil dengan angka $<0,5 \%$. Daun mint dalam bentuk kapsul atau yang dibuat sebagai teh bisa meringankan mual dan gangguan pencernaan. Daun mint berpotensi memperlancar sistem pencernaan dan meringankan kejang perut.

Hasil penelitian ini sesuai dengan Penelitian Merat, Khalili, \& Mostajabi (2010) yang menyatakan tingkat keparahan nyeri abdomen menurun secara signfikan pada penggunaan Mint jika dibandingkan dengan plasebo $(p=0,001)$, bahkan kualitas hidup responden dengan penggunaan Mint juga meningkat. Mint efektif dan aman untuk mengatasi Irritable Bowel Syndrome (IBS) dari nyeri dan ketidaknyamanan abdomen.

Penelitian ini dilakukan dengan meminum hangat ekstrak mint, hasil penelitian ini berbeda dengan penelitian Pasha et al., (2014) yang mengurangi mual muntah dengan pemberian larutan mint murni (4 tetes) yang letakkan di bawah tempat tidur ibu hamil secara rutin selama
4 malam berturut-turut sebelum tidur, sedangkan kelompok kontrol dengan lautan air yang dicampur 4 tetes normal saline. Hasil penelitian menunjukkan bahwa tingkat keparahan mual dan muntah di kedua grup pada 7 hari sebelum dan sesudah intervensi tidak ada perbedaan, namun selama intervensi tingkat keparahan mual mengalami tren yang menurun (khususnya di malam keempat) pada kelompok intervensi. Kebalikannya pada kelompok grup, tingkat keparahan mual mengalami trend yang meningkat. Tingkat keparahan mual pada 7 hari paska intervensi mempunyai tren yang menurun di kedua grup, walaupun intensitasnya lebih rendah pada kelompok intervensi.

Pemberian ekstrak daun mint yang disajikan dalam bentuk minuman hangat dapat menjadi alternatif dalam mengurangi mual muntah ibu hamil trimester I. Pemanfaatan tanaman obat keluarga akan sangat membantu dalam mengurangi mual muntah dan mencegah terjadinya hiperemesis gravidarum.

\section{Perbedaan Rerata Mual Muntah Ibu Hamil Trimester I yang Diberikan Ekstrak Jahe, Daun Mint dan Kelompok Kontrol}

Hasil uji statistik pada penelitian ini didapatkan tidak ada perbedaan yang signifikan rata-rata mual muntah antara ibu yang mendapatkan ekstrak jahe dengan ibu yang mendapat ekstrak mint $(p=0,548$. Tidak ada perbedaan yang signifikan rata-rata mual muntah antara ibu yang mendapatkan ekstrak jahe dengan ibu pada kelompok kontrol (pengobatan standar puskesmas/ pemberian vitamin B6) $p=0,807$. dan tidak ada perbedaan yang signifikan rata-rata mual muntah antara ibu yang mendapatkan ekstrak mint dengan ibu pada kelompok kontrol (pengobatan standar puskesmas/pemberian vitamin B6) $p=0,407$.

Hasil penelitian ini berbeda dengan penelitian Parwitasari, Utami dan Rahmalia (2014) yang menyatakan pemberian rebusan jahe lebih efektif dibandingkan dengan daun mint. Perbedaan hasil penelitian ini dapat terjadi terkait selera terhadap aroma minuman yang disukai oleh responden, jahe lebih mudah diperoleh dan lebih sering diminum oleh masyarakat, sedangkan mint lebih banyak digunakan sebagai aromaterapi dalam mengurangi mual dan muntah.

Hasil penelitian ini menjelaskan bahwa ketiga intervensi pemberian ekstrak jahe, mint dan pengobatan standar puskesmas dengan pemberian B6 tidak mempunyai perbedaan, hal ini menunjukkan bahwa ketiga terapi memberikan efek menurunkan mual muntah pada 
ibu hamil. Hal ini menjelaskan bahwa ibu hamil dapat memilih alternatif terapi pencegahan mual muntah yang sesuai dengan kemampuan dan ketersediaan sumber alam yang ada di lingkungan sekitar. Hasil penelitian ini dilakukan pada ibu hamil yang mengalami mual muntah derajat ringan. Penelitian ini merekomendasikan penelitian lanjut terkait dosis pemberian yang tepat dalam menurunkan mual muntah derajat sedang dan berat pada ibu hamil, efek samping serta penggunaan pada kondisi klien mual muntah pada klien dengan permasalahan saluran cerna yang lain.

\section{SIMPULAN}

Kesimpulan hasil penelitian ini adalah:

1. Ibu hamil yang mengalami mual muntah terbanyak pada rentang usia 20-35 tahun sejumlah $86(84 \%)$, pendidikan pada kategori SMA sejumlah 39 orang (38\%), tidak bekerja sejumlah 82 orang $(80 \%)$ dan pada paritas 12 sejumlah $74(73 \%)$.

2. Tidak ada pengaruh umur, pendidikan, pekerjaan terhadap mual muntah ibu hamil trimester I, $(p=0,423, \quad p=0,06, \quad p=0,36)$. Terdapat pengaruh signifikan antara paritas dengan mual muntah yang terjadi pada ibu hamil trismester I nilai $p=0,01$, nilai $\mathrm{OR}$ 3,412 artinya ibu primigravida memiliki peluang mual muntah pada kehamilan trimester pertama sebanyak 3,4 kali dibandingkan ibu multigravida.

\section{DAFTAR PUSTAKA}

Bishop, J. L., Northstone, K., Green, J. R., \& Thompson, E. A. 2011. The use of Complementary and Alternative Medicine in pregnancy: Data from the Avon Longitudinal Study of Parents and Children (ALSPAC). Complementary Therapies in Medicine, 19(6), 303-310. http://doi.org/10.1016/j.ctim.2011.08.005

Broussard, C. S., Louik, C., Honein, M. A., \& Mitchell, A. A. 2010. Herbal use before and during pregnancy. American Journal of Obstetrics and Gynecology, 202(5), 443.e1-443.e6. http://doi.org/10.1016/j.ajog.2009.10.865

Chan, R. L., Olshan, A. F., Savitz, D. A., Herring, A. H., Daniels, J. L., Peterson, H. B., \& Martin, S. L. 2011. Maternal influences on nausea and vomiting in early
3. Terdapat perbedaan signifikan antara pengukuran nilai mual muntah sebelum dan setelah pemberian ekstrak jahe, ekstrak mint dan kelompok kontrol dengan nilai $p=0,001$ pada pemberian ekstrak jahe, nilai $p=0,000$ pada pemberian ekstrak mint, dan $p=0,001$ pada kelompok kontrol (pengobatan standar puskesmas dengan vitamin B6).

4. Tidak terdapat perbedaan rerata mual muntah ibu hamil trimester I yang mendapat ekstrak jahe dan mint $(p=0,548)$, ekstrak jahe dan kelompok kontrol $(p=0,807)$, ekstrak mint dan kelompok kontrol $(p=0,407)$.

\section{SARAN}

Jahe dan mint dapat menjadi terapi alternatif mengurangi mual muntah derajat ringan pada ibu hamil trimester I dan merupakan alternatif terapi pencegahan hiperemesis gravidarum. Ibu hamil dapat memanfaatkan sumber alam yang ada di sekitar rumah/ dan memanfaatkan tanaman obat keluarga terutama tumbuhan jahe dan mint.

Penelitian lanjutan tentang penggunaan tanaman herbal yang ada di tanaman obat keluarga dalam upaya preventif terhadap perubahan fisiologis pada ibu hamil. Penelitian lanjut tentang komposisi, dosis yang tepat dalam mengurangi mual muntah pada ibu hamil, dan efek samping serta kemanfaatan jahe dan mint terhadap masalah gangguan saluran cerna yang mengalami mual dan muntah ringan.

pregnancy. Maternal and Child Health Journal, 15(1), 122-127. http://doi.org/10.1007/s10995-009-0548-0

Depkes RI \& Usaid. 2013. Program Perencanaan Persalinan dan Komplikasi dan Pencegahan Komplikasi (P4K) dalam rangka mempercepat penurunan AKI \& $A K B$. Jakarta.

Dinas Kesehatan Propinsi Lampung. 2014. Profil Kesehatan Propinsi Lampung Tahun 2014. Lampung.

Einarson, T. R., Piwko, C., \& Koren, G. 2013. Quantifying the global rates of nausea and vomiting of pregnancy: A meta-analysis. Journal of Population Therapeutics and Clinical Pharmacology, 20(2), 23863575.

Heitmann, K., Holst, L., Lupattelli, A., Maltepe, C., \& Nordeng, H. 2015. Treatment of 
nausea in pregnancy: a cross-sectional multinational web-based study of pregnant women and new mothers. BMC Pregnancy and Childbirth, 15(1), 1-13. http://doi.org/10.1186/s12884-015-0746-2

Isbir, G. G., \& Mete, S. 2013. Experiences with nausea and vomiting during pregnancy in Turkish women based on Roy adaptation model: A content analysis. Asian Nursing Research, 7(4), 175-181. http://doi.org/10.1016/j.anr.2013.09.006

Kikak, Choiriyah, Z., \& Trisnasari, A. 2013. Efektifitas konsumsi ekstrak jahe dengan frekuensi mual muntah pada ibu hamil di wilayah kerja puskesmas ungaran tahun 2013. Stikes Ngudi Waluyo.

Lacasse, A., Rey, E., Ferreira, E., Morin, C., \& Bérard, A. 2009. Epidemiology of nausea and vomiting of pregnancy: prevalence, severity, determinants, and the importance of race/ethnicity. BMC Pregnancy and Childbirth, 9, 26. http://doi.org/10.1186/1471-2393-9-26

Lee., N. ., \& Saha, S. 2011. Nausea and Vomiting of Pregnancy. Gastroenterol Clin North Am, 40(2), 1-27. http://doi.org/10.1016/j.gtc.2011.03.009.N ausea

Locock, L., Alexander, J., \& Rozmovits, L. (2008). Women's responses to nausea and vomiting in pregnancy. Midwifery, 24(2), $143-152$. http://doi.org/10.1016/j.midw.2006.12.001

Louik, C., Hernandez-Diaz, S., Werler, M. M., \& Mitchell, A. A. 2006. Nausea and vomiting in pregnancy: Maternal characteristics and risk factors. Paediatric and Perinatal Epidemiology, 20(4), 270-278. http://doi.org/10.1111/j.13653016.2006.00723.x

Merat, S., Khalili, Æ. S., \& Mostajabi, Æ. P. 2010. The Effect of Enteric-Coated, Delayed-Release Peppermint Oil on Irritable Bowel Syndrome, 1385-1390. http://doi.org/10.1007/s10620-009-0854-9

Munch, S., Korst, L., Hernandez, G., Romero, R., \& Goodwin, T. 2010. Health-related quality of life in women with nausea and vomiting of pregnancy: the importance of psychosocial context. Journal of Perinatology, 31(10), 10-20. http://doi.org/10.1038/jp.2010.54

Niebyl, J. R. 2010. Nausea and vomiting in pregnancy. New England Journal of Medicine, 363(16), 1544-50. http://doi.org/10.1016/B978-0-12-4080782.00005-6

Ozgoli, G., Goli, M., \& Simbar, M. 2009. Effects of ginger capsules on pregnancy, nausea, and vomiting. Journal of Alternative and Complementary Medicine, 15(3), 243-246. http://doi.org/10.1089/acm.2008.0406

Pasha, H., Behmanesh, F., Mohsenzadeh, F., Hajahmadi, M., \& Aa, M. 2014. Study of the effect of mint oil on nausea and vomiting during pregnancy . PubMed Commons. Iran Red Crescent Med J, 14(2), 1-2. http://doi.org/10.5812/ircmj.3477.

Parwitasari, C. D., \& Utami, S. 2014. Perbandingan Efektivitas Pemberian Rebusan Jahe Dan Daun Mint Terhadap Mual Muntah Pada Ibu Hamil. Jurnal Online Mahasiswa Program Studi Ilmu Keperawatan Universitas Riau, 1(1), 1-10.

Rhodes, V., \& McDaniel, R. 2001. Nausea, vomiting and retching: Complex problem in palliative care. A Cancer Journal for Clinicians, 51(4), 232-248. http://doi.org/10.3322/canjclin.51.4.232

The American College of Obstetricians and gynecologists, T. A. C. of O. and gynecologists. 2015. Morning sickness: Nausea and vomiting of pregnancy. Retrieved from http://www.acog.org/ /media/For Patients/faq126.pdf

Viljoen, E., Visser, J., Koen, N., \& Musekiwa, A. 2014. A systematic review and metaanalysis of the effect and safety of ginger in the treatment of pregnancy-associated nausea and vomiting. Nutrition Journal, 13(1), 20. http://doi.org/10.1186/14752891-13-20

White, P. F., \& Leon-casasola, O. A. De. 2009. Nausea and Vomiting. Society, (November 2008), 1-8. 